\title{
ACTIVITY OF STRAINS OF METARHIZIUM ANISOPLIAE (METSCH) SOROKIN AGAINST WHITE GRUB (CHILOLOBA ACUTA, SCARABAEIDAE, COLEOPTERA) UNDER LABORATORY CONDITION IN NEPAL
}

Dipak Khanal ${ }^{1}$

\begin{abstract}
Soil insect pests are the major productivity constrains of different crops among which white grubs (Coleoptera: Scarabaeidae), both adult and larval stages, are extremely destructive in nature. Laboratory studies were conducted to evaluate the virulence of an indigenous and a commercial strain of the entomopathogenic fungi, Metarhizium anisopliae (Metsch.) Sorokin, against white grubs species Chiloloba acuta by applying the dipping method at Entomology Division, NARC, Nepal. Third instars larvae of C. acuta were dipped in suspensions of indigenous and commercial strains (Pacer) of M. anisopliae at different concentrations ranging from $3.33 \times 10^{4}$ to $1.04 \times 10^{8}$ spores $/ \mathrm{ml}$ for $3-5$ seconds which resulted in $97.8 \%$ and $89 \%$ mortalities with the highest dose of $1.04 \times 10^{8} \mathrm{spores} / \mathrm{ml} 40$ days after inoculation (DAl), respectively. The $L C_{50}$ values for indigenous and commercial strain were $3.5 \times 10^{5}$ and $1.88 \times 10^{6}$ spores $/ \mathrm{ml}$, respectively, with the potency of 1:0.28 at 40 DAl. Bioassays were conducted in completely randomized design. From results it is concluded that the tested strains of entomopathogenic fungi have potential as microbial control agents in managing white grubs in laboratory and it is suggested to be tested under farmers field condition.
\end{abstract}

Key words: Bioassay, coleoptera, Entomopathogenic fungi, $\mathrm{LC}_{50}$, irulence, white grubs

\section{INTRODUCTION}

Insect pests are the major limiting factor to crop production systems, which cause about $12-15 \%$ crop losses worldwide (Upadhyaya, 2003) and 15- 20\% in Nepal (Joshi et al., 1991; Palikhe et al., 2003). Among them soil insect pests are becoming major biological constraints to the productivity of different upland crops (Oya, 1996; Guppy and Harcourt, 1970; Potter et al., 1992). The extent of damage caused by white grubs solely depends upon the species involved, the number present and the host crops. The damage caused by scarab larvae is estimated to reduce the crop yield by about $40-80 \%$ (Prasad and Thakur, 1959; Raodeo, 1974), and in a more recent study by about $12-60 \%$ (Pokhrel, 2004). However, insecticides have been found ineffective in controlling scarab larvae (NMRP, 1997) because the larvae present in the soil do not come into direct contact with the insecticides, which is generally applied during the growing season (Oya, 1995) and have even shown resistance to organochlorine (Pokhrel, 2004). Scheduled chemical methods are ineffective (Schweigkofler and Zelger, 2002) and farmers are not considering economic thresholds of these pests, but applying pesticides at higher dosages than it is required (Maharjan et al., 2004).

The entomopathogenic fungus (EPF) Metarhizium anisopliae (Metschn.) Sorokin is one of the most reviewed, studied and applied species amongst fungal bio-control agents, and several commercial products have been developed and registered for the control of different insect pests (Butt et al., 2001; Ferron, 1985; Upadhyay, 2003). M. anisopliae, as being environmentally friendly and also likely to be self-perpetuating (Mazodze et al., 1999) and has no mammalian toxicity.

Microbial control has evolved worldwide as an important component of integrated pest management (IPM), with success in Asia and South America (Fuxa, 1987) although it is still in developing stages in Nepal (G.C, 2006). The evaluation of the efficacy of M. anisopliae in the field and in the laboratory with both indigenous as well as commercial isolates is of prime importance to answer the growing debate on the use of indigenous ones (Gurung, 1985; Katuwal, 1998; Khanal et al., 2014). Hence M. anisopliae has been used as a biological control agent in this study for possible integration in the IPM program in order to replace synthetic insecticides with their negative effects.

$\overline{1 \text { TU, IAAS, Paklihawa Campus, Paklihawa, Rupandehi }}$ 


\section{MATERIALS AND METHODS}

\section{FUNGUS STRAINS}

Two strains of $M$. anisopliae, an indigenous and a commercial one, were used in this experiment. The indigenous strain was obtained from the Insect Pathology Unit, Entomology Department, Institute of Agriculture and Animal Science. The commercial product, named "Pacer" manufactured by Agri Life Medak, India, obtained from a non-governmental organization, the International Development Enterprises (IDE) based in Kathmandu. This wettable powder (WP) formulation contains $1.15 \%$ of $M$. anisopliae corresponding to $10^{8}$ conidia forming units (CFU) per $g$ dry weight of the product.

For conidia production of the indigenous strain, the selective medium Sabouraud Dextrose Agar (SDA) adopted from Strasser et al. (1997) with the following composition was used: $20 \mathrm{~g}$ dextrose, $10 \mathrm{~g}$ peptone, $18 \mathrm{~g}$ agar-agar, $0.6 \mathrm{~g}$ streptomycine, $0.05 \mathrm{~g}$ tetracycline, and $0.05 \mathrm{~g}$ cyclohexamide and $1000 \mathrm{ml}$ of distilled water. Autoclaved (at $1.5 \mathrm{bar}, 121^{\circ} \mathrm{C}$, for $40 \mathrm{~min}$ ) medium was poured in Petri dishes and allowed to solidify under laminar air flow. Then M. anisopliae was inoculated on solid media using loops and the Petri dishes incubated at $24^{\circ} \mathrm{C}$ and $75 \% \mathrm{RH}$ for growth and sporulation of the fungus in an aseptic condition. After 16 days, they were used in bioassay.

\section{INSECT COLLECTION}

For the bioassays, white grubs were collected from Kulekhani VDC, Ward-7 of the Makawanpur district (85¹8'605 N, 2759'900 E, 1530 masl). The collected white grubs were placed individually in $100 \mathrm{ml}$ vials $(5 \mathrm{~cm} \times 5.5 \mathrm{~cm}, \mathrm{~d} \times \mathrm{h})$ containing soil and covered with a perforated lid. In the laboratory of the Entomology Division NARC, Lalitpur, white grubs were transferred into rearing vials $(5 \mathrm{~cm} \times 5.5 \mathrm{~cm}, \mathrm{~d} \times \mathrm{h})$ filled with soil obtained from the field where the grubs were collected. The rearing vials were kept under ambient room temperature $\left(25 \pm 5^{\circ} \mathrm{C} ; 75 \pm 5 \% \mathrm{RH}\right)$ for 10 days. Any larva that showed symptoms of a disease during this quarantine period was discarded. After a week, the soil and feeding material were changed. Only non-infected and morphologically identical larvae were used in the bioassays.

SOIL ANALYSIS

To study physio-chemical properties of the soil, samples were taken from the collected soil and analyzed at the Soil Division, NARC, Khumaltar. The soil texture was determined by the hydrometer method and $\mathrm{pH}$ by a digital $\mathrm{pH}$ meter. Soil $\mathrm{pH}$ was 5.5 . The soil was composed of sand $61.3 \%$, silt $28.5 \%$, clay $20.2 \%$ and consequently classified as silty loam.

\section{BIOASSAY}

The bioassays were conducted at Entomology Division, NARC, Khumaltar. Soil, from the insect collected area, was carried, sieved and then sterilized (autoclaved at 15 bar, $121^{\circ} \mathrm{C}$ for $1 \mathrm{~h}$ ) and kept sealed at room temperature until one day before use. The vials $(100 \mathrm{ml}, 6 \times 5.5 \mathrm{~cm}$, h $\times \mathrm{d})$ with perforated lids for better aeration were filled $3 / 4$ with this sterilized soil.

The concentration (conidia per $\mathrm{ml}$ ) was determined by using a Thoma Haemocytometer (Sigma). The conidia of the indigenous strain of $M$. anisopliae were harvested by scraping off the contents from each Petri dish with a sterile metal spatula into a beaker containing $120 \mathrm{ml}$ distilled water. Two drops of Tween $20(0.1 \%)$ were added as dispersing agents. In another beaker the commercial strain of M. anisopliae was mixed in $120 \mathrm{ml}$ water along with 2 drops of Tween $20(0.1 \%)$ which were kept for fifteen minutes to allow talcum residue settle down. From the prepared solutions, $1 \mathrm{ml}$ solution 
was taken and the conidia counted using haemocytometer and microscope (at $40 \times$ magnification, stereomicroscope, Model SZX ILLD200, No. at FO 4725, Olympus, Japan). Conidia were added to the suspension and the counting repeated until the required concentration of $1.04 \times 10^{8}$ conidia per $\mathrm{ml}$ were obtained which was further diluted to obtain the different concentration levels $\left(1.04 \times 10^{8}\right.$, $2.08 \times 10^{7}, 4.16 \times 10^{6}, 8.32 \times 10^{5}, 1.66 \times 10^{5}, 3.32 \times 10^{4}$ ) using five as dilution factor. The titer of the suspensions was calculated using the formula "C1V1 = C2V2", where C1, V1 are initial concentration and initial volume and $\mathrm{C} 2$, V2 are final concentration and final volume, respectively.

The experiments were completely randomized. Each treatment (strain and concentration level) was tested with $n=50$ larvae of $C$. acuta; i.e. a total number of $N=(2 \times 6 \times 50)+(50$ control $)=650$ were used in the bioassay. Each test insect was dipped into $100 \mathrm{ml}$ of the required suspensions (concentration level) of the respective M. anisopliae strain (either indigenous or commercial) for about 5 seconds. An additional number of 50 larvae were dipped into distilled water mixed with Tween 20 only, which served as control. The excess water was removed by placing the wet larvae on tissue paper before transferring individually to $100 \mathrm{ml}$ plastic vials containing $40 \mathrm{~g}$ of sterilized soil and a slice of potato as food source. Larvae that had not entered the soil within 15 minutes were considered injured and replaced.

\section{OBSERVATIONS}

Mortality was assessed through direct observation of larvae in one-day interval from 10 days after inoculation (DAl) to $40 \mathrm{DAl}$. During evaluation dead larvae without visible fungal symptoms were removed from the plastic vial, placed individually in a Petri dish with filter paper ( $9 \mathrm{~cm}$ diameter) and incubated at $25^{\circ} \mathrm{C}$ and $85 \% \mathrm{RH}$ for 7-10 days to allow mycelia growth. The cause of death was confirmed by microscopic examination of the outgrowing fungus.

Daily room temperature was recorded up to 40 days from the beginning of the experiment. The maximum and minimum temperatures recorded were $29.7^{\circ} \mathrm{C}$ and $24.0^{\circ} \mathrm{C}$ on July 7 and July 13 , respectively.

\section{DATA ANALYSIS}

The data from the bioassays were analyzed to assess the dose-time mortality curves for each of the M. anisopliae strain tested. First, survival data from each evaluation date were submitted to Probit analysis according to Finney (1971) to determine the dose-mortality relationship for each DAI. LC $5^{-}$values and the slope of regression lines with their corresponding standard errors and confidence bands were determined for each DAI. Data from the same experiments were analyzed in a parallel assay. Parallelism was evaluated using a Likelihood $\mathrm{Chi}^{2}$-test (G-test). If the regression lines were acceptably parallel $(p>0.05)$ a common slope was used for all Probit lines. Observed mortalities were adjusted for control mortality (dead test insects without signs of fungal disease) using Abbott's formula (Abbott 1925). Estimation of the natural mortality rate was included into the Probit model (Finney, 1971):

\section{RESULTS}

Biological activity of $M$. anisopliae against $C$. acuta

Two experiments were conducted with indigenous and commercial M. anisopliae. The Probit model adequately describes the relationship between the fungus concentration and the mortality response in C. acuta for all evaluation dates after fungus application (Figure 1).(Table 2). 


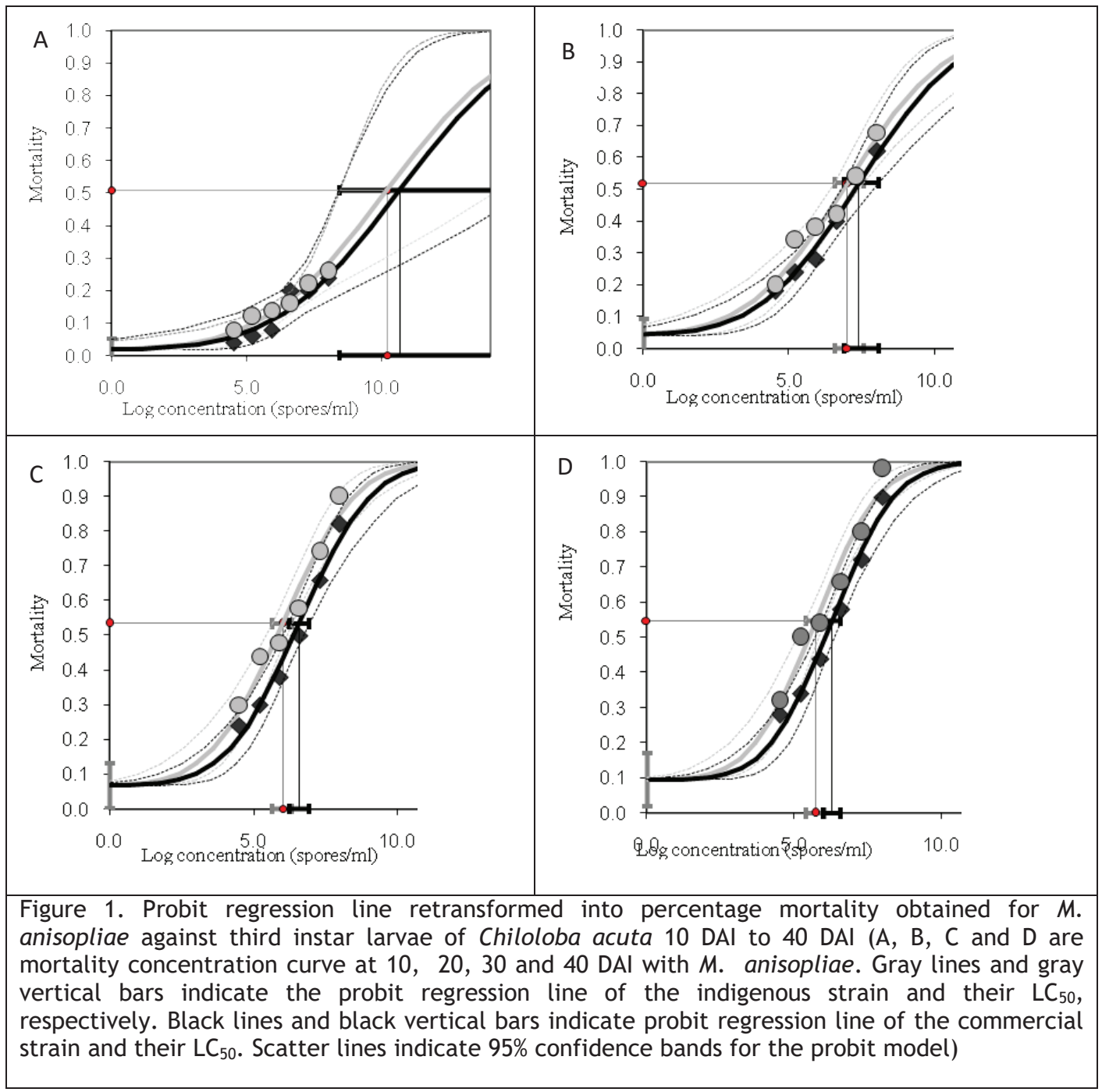

The intercepts of the probit regression lines changed with increasing incubation time (Figure 2). At the beginning of the experiment, intercepts increased from 10 to 14 DAl, thereafter values decreased gradually up to 40 DAI (Table 2 ). 


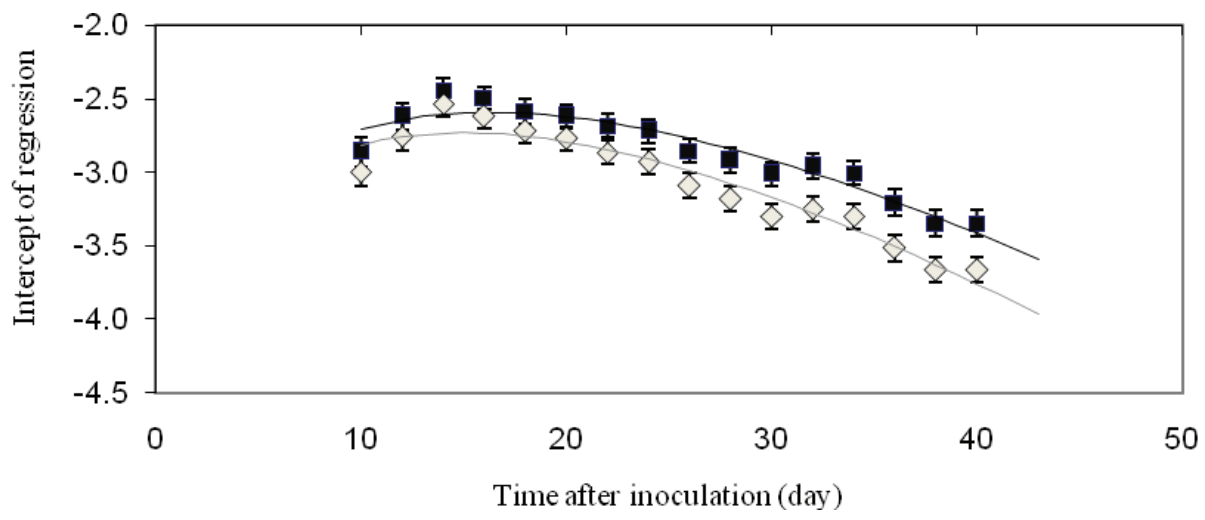

Figure 2. Intercepts of probit regression lines obtained during testing of the indigenous strain (black line) and commercial strain (gray line) strain of $M$. anisopliae against $C$. acuta at different DAI

The following non-linear model was successfully fitted to describe the relationship between time after inoculation and the intercept for both stains.

intercept $=a+b x+c \sqrt{x}$

In which, $x$ is DAl. The model explained $92 \%$ and $93 \%$ of the variation in intercept over time for indigenous and commercial strains of M. anisopliae respectively (Figure 3), see model parameters and statistical details in Table 1.

Table 1. Resulting parameters in regression statistics for describing the relationship between intercept resulting from the probit analysis and DAl for the commercial and indigenous strains of M. anisopliae against $C$. acuta

\begin{tabular}{lccccccc}
\hline Strain & \multicolumn{3}{c}{ Parameters } & $\mathrm{R}^{2}$ & $\mathrm{~F}$ & $\mathrm{df}$ & $\mathrm{P}$ \\
\cline { 2 - 4 } & $\mathrm{a}$ & $\mathrm{b}$ & $\mathrm{C}$ & & & & \\
\hline Indigenous & -5.139 & -0.157 & 1.263 & 0.917 & 71.4 & 13 & $<0.001$ \\
& $(0.589)$ & $(0.026)$ & $(0.252)$ & & & & \\
Commercial & -5.275 & -0.170 & 1.316 & 0.925 & 80.0 & 13 & $<0.001$ \\
& $(0.708)$ & $(0.032)$ & $(0.303)$ & & & & \\
\hline
\end{tabular}

$\mathrm{a}, \mathrm{b}$ and $\mathrm{c}$ are model parameters, number in parentnesis indicate standard error. $p=$ probability. $F=$ Fisher test, $R^{2}=$ Coeffecient of determination, $d f=$ degree of freedom

The slopes of the regression lines were not significantly different between the two stains of $M$. anisopliae throughout the evaluation period as indicated by $\mathrm{Chi}^{2}$ values for parallelism (Table 2). Slope increased from 0.2811 at 10 DAl to 0.5820 at 40 DAl almost linearly (Figure 3). Linear regression explained $99 \%$ of the variability of the common slope by DAl. The slope increased by a value of 0.011 (SE 0.0003) per day $(F=1490, d f=14, p<0.001)$. 


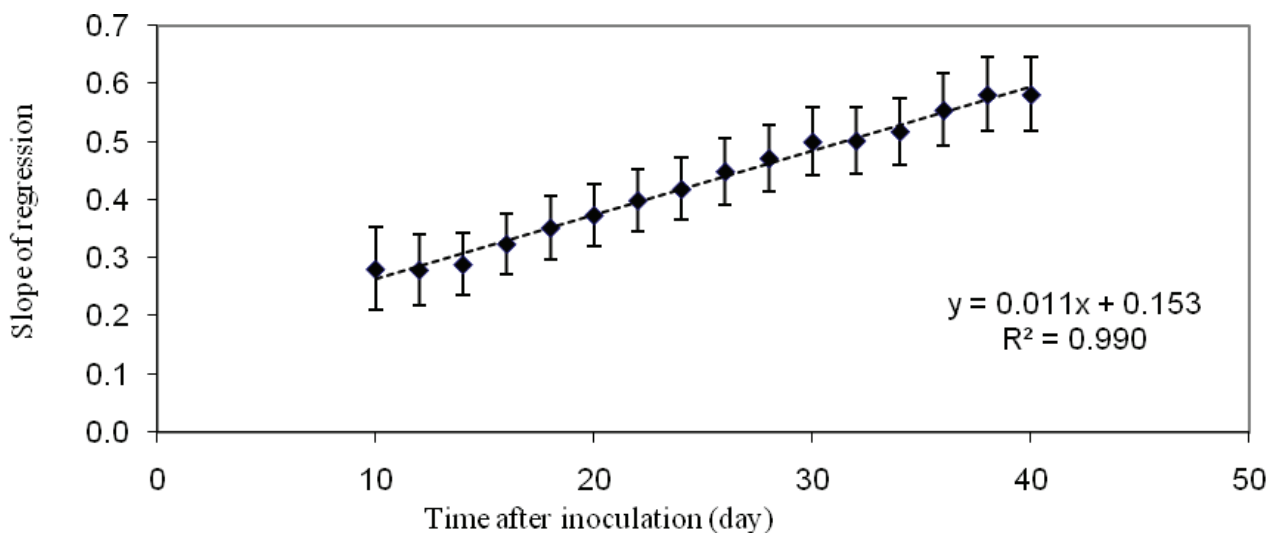

Figure 3. Regression line obtained from common slope of probit regression line during the comparison of the indigenous and the commercial strain of $M$. anisopliae against third instars of $C$. acuta (Black points indicate the common slope and the dotted line shows the regression line fitted between the common slope of the probit models and time after fungus application)

Lethal time was inversely propotional to the concentration of $M$. anisopliae. With the increase in the concentration level of M. anisopliae the lethal time of both strains (indigenous and commercial) decreased. Lethal time required for the indigenous strain was less than commercial strain with same concentration (Table 2, Figure 4).

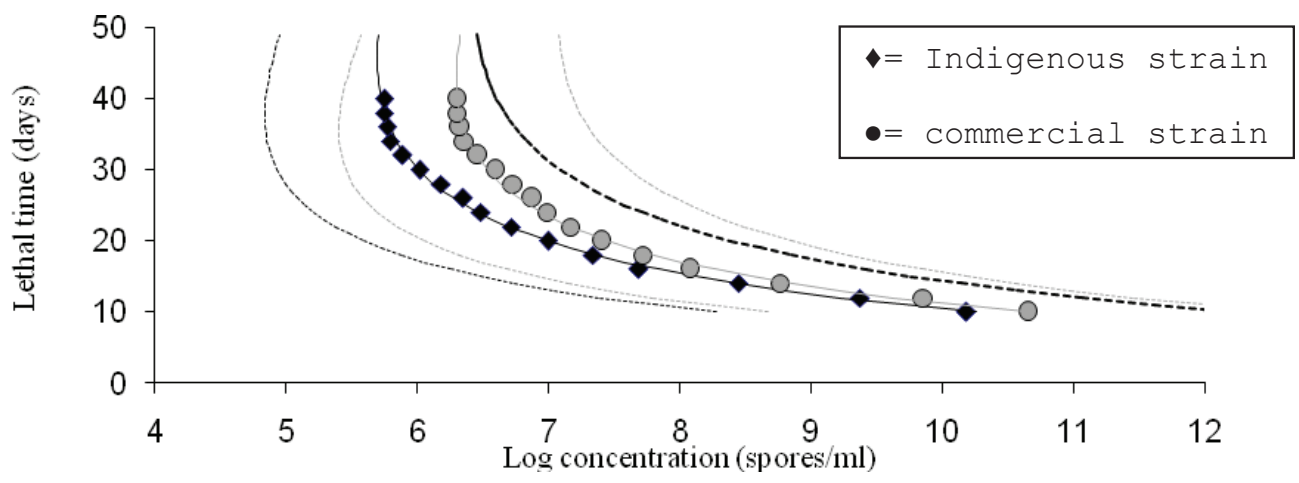

Figure 4. $\mathrm{LC}_{30}, \mathrm{LC}_{50}, \mathrm{LC}_{70}$ value of indigenous (black line) and commercial (gray line) strain of $M$. anisopliae obtained in bioassay 


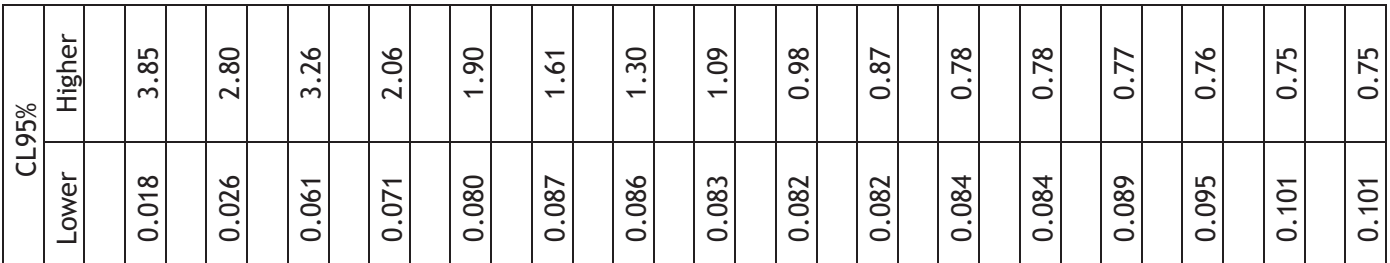

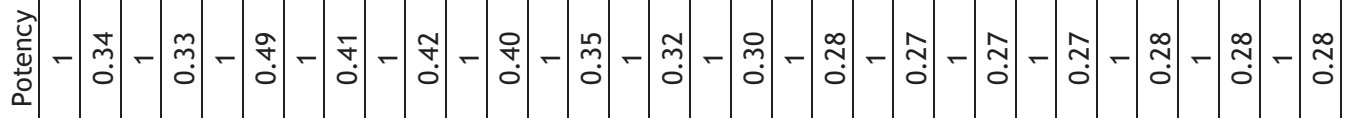

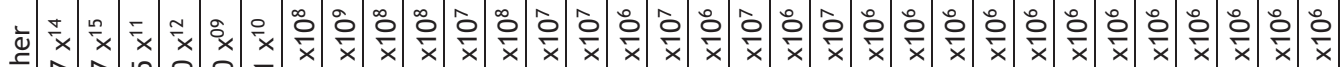
些 ㅇํํำ

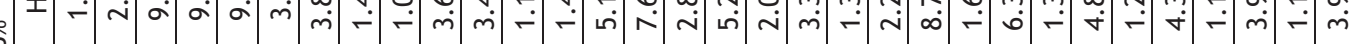

U

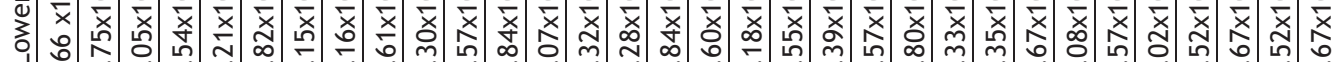

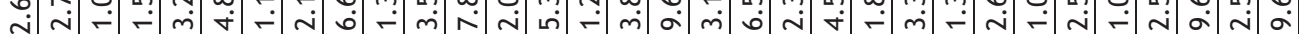

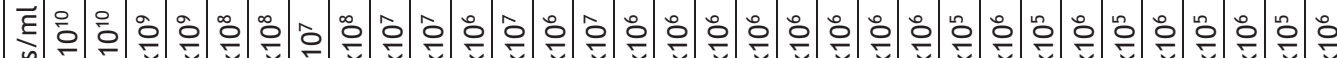

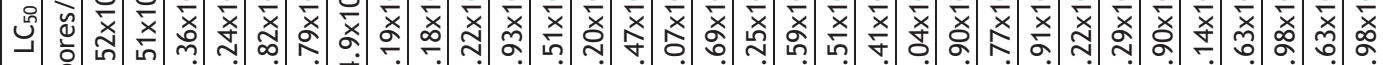

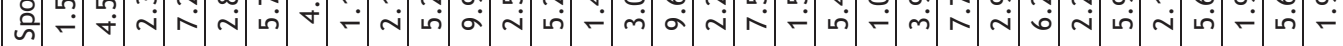

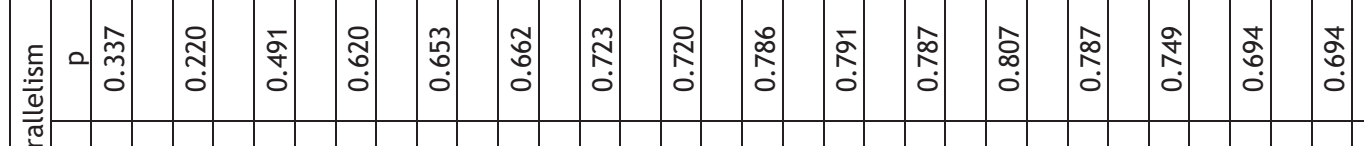

శై

\begin{tabular}{|c|c|c|c|c|c|c|c|c|c|c|c|c|c|c|c|c|c|}
\hline 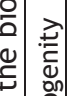 & $\circ$ & $\begin{array}{l}\bar{\alpha} \\
\alpha \\
0\end{array}$ & ৪ே & $\mid \begin{array}{l}\hat{\alpha} \\
\alpha \\
\dot{\alpha}\end{array}$ & 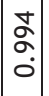 & $\begin{array}{l}\mathbf{2} \\
\mathbf{0} \\
0 \\
0\end{array}$ & 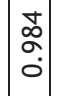 & $\mid \begin{array}{l}\mathbb{1} \\
\hat{\alpha} \\
0 \\
0\end{array}$ & \begin{tabular}{|l}
$\bar{\alpha}$ \\
$\alpha$ \\
0 \\
0
\end{tabular} & $\mid \begin{array}{l}\hat{\alpha} \\
\hat{\alpha} \\
0\end{array}$ & $\overline{\tilde{\alpha}}$ & $\begin{array}{l}0 \\
\text { f } \\
0 \\
0\end{array}$ & $\mid$\begin{tabular}{l}
0 \\
\multirow{2}{0}{} \\
0
\end{tabular} & $\begin{array}{l}\bar{\alpha} \\
0 \\
0 \\
0\end{array}$ & $\mid$ & $\begin{array}{c}\tilde{\sigma} \\
\stackrel{\alpha}{\circ} \\
\dot{0}\end{array}$ & 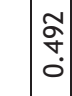 \\
\hline
\end{tabular}

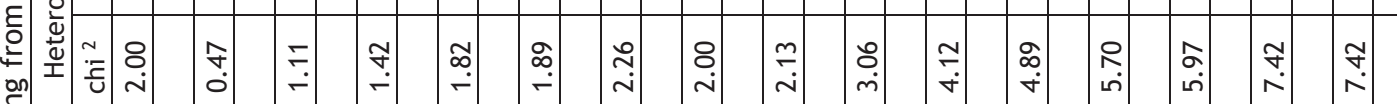

\begin{tabular}{|c|c|c|c|c|c|c|c|c|c|c|c|c|c|c|c|c|c|c|c|c|c|c|c|}
\hline $\bar{\tau}$ & i & & 。 & - & & - & - & - & & i & i & & i & $m$ & $\nabla$ & & $\dot{\nabla}$ & เ่ं & เ & & $\sim^{\circ}$ & r & \\
\hline 岕 & זٓ & & $\begin{array}{l}8 \\
0 \\
0 \\
0\end{array}$ & 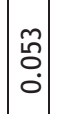 & & $\begin{array}{l}5 \\
\circ \\
0 \\
0\end{array}$ & 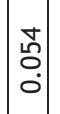 & นึ. & & 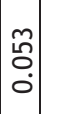 & $\begin{array}{l}2 \\
\stackrel{2}{0} \\
0 \\
0\end{array}$ & & $\begin{array}{l}\hat{5} \\
0 \\
0\end{array}$ & 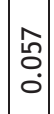 & 离 & & $\begin{array}{l}10 \\
0 \\
0 \\
0\end{array}$ & $\begin{array}{l}\hat{2} \\
0 \\
0 \\
0\end{array}$ & ç & & $\left|\begin{array}{l}n \\
0 \\
0 \\
0\end{array}\right|$ & $\begin{array}{l}n \\
0 \\
0 \\
0\end{array} \mid$ & \\
\hline $\begin{array}{l}\frac{0}{0} \\
\text { ज }\end{array}$ & $\mid \begin{array}{c}\bar{c} \\
\stackrel{2}{0} \\
0 \\
0\end{array}$ & & 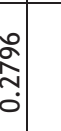 & 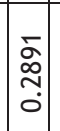 & & 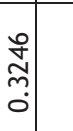 & $\begin{array}{c} \pm \\
\text { గn. } \\
\sim \\
0\end{array}$ & $\begin{array}{l}\mathfrak{m} \\
m \\
0\end{array}$ & & $\mid \begin{array}{c}0 \\
2 \\
\tilde{\sigma} \\
0\end{array}$ & $\begin{array}{l}\tilde{\sigma} \\
\sigma \\
\sigma \\
0\end{array}$ & & 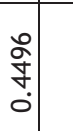 & $\mid \begin{array}{c}\mathfrak{N} \\
\mathfrak{f} \\
\dot{0}\end{array}$ & $\begin{array}{l}\infty \\
\text { ç } \\
c\end{array}$ & & 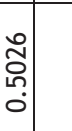 & $\mid \begin{array}{c}2 \\
\infty \\
\\
0 \\
0\end{array}$ & 占 & & 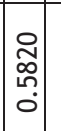 & 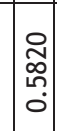 & \\
\hline 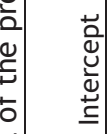 & $\mid \begin{array}{c}n \\
\infty \\
\infty \\
\\
1\end{array}$ & 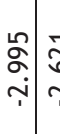 & 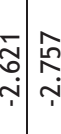 & $\begin{array}{c}\tilde{y} \\
\stackrel{\sim}{y} \\
\stackrel{1}{*}\end{array}$ & 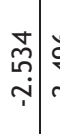 & 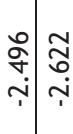 & $\mid \begin{array}{l}\infty \\
\infty \\
\sim \\
\sim \\
\sim\end{array}$ & 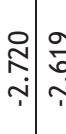 & 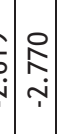 & 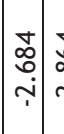 & 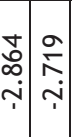 & 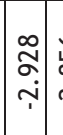 & 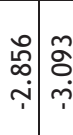 & 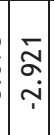 & 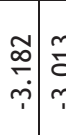 & 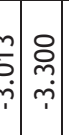 & 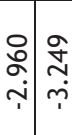 & $\begin{array}{l}+ \\
\delta \\
r \\
r\end{array}$ & $\begin{array}{l}\infty \\
\stackrel{2}{2} \\
\\
\end{array}$ & $\begin{array}{c}0 \\
\stackrel{0}{n} \\
\\
\end{array}$ & $\begin{array}{c}\hat{f} \\
m \\
r \\
r\end{array}$ & 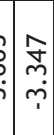 & \\
\hline 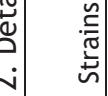 & - & $\cup-$ & $-u$ & - & $u-$ & $-u$ & - & $u-$ & $u$ & -1 & $v-$ & $u$ & $-u$ & - & $u-$ & $-u$ & $-u$ & -4 & $u-$ & $u$ & -1 & - & \\
\hline $\bar{\Xi}$ & 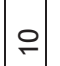 & ? & $\stackrel{N}{\simeq}$ & \pm & & $\stackrel{0}{\circ}$ & $\stackrel{\infty}{-}$ & ก & & הี & $\sqrt{-1}$ & & $\stackrel{\sim}{\sim}$ & $\stackrel{\infty}{\sim}$ & $\stackrel{\Upsilon}{~}$ & P & $\tilde{m}$ & $\stackrel{m}{m}$ & লొ & & $\stackrel{\infty}{m}$ & 우 & \\
\hline
\end{tabular}




\section{DISCUSSIONS}

An indigenous and a commercial strain of M. anisopliae were assessed to determine the biological activities of these strains using the dipping method. Both strains were significantly effective to cause mortality to the test insects. The common slope for the microbial agents rarely exceeds above 2. It was believed that the pathogens which caused infectivity without producing toxins produced slopes predominantly below 2 (Burges and Thomson, 1971). The value of slopes exceeding 2, might be expected with pathogens like Bt (that produce toxin), but this also depends on the strain used and the host treated (Meynell and Meynell, 1965).

The present study was performed to evaluate the virulence of two strains of $M$. ansiopliae for controlling white grubs under laboratory conditions. The result revealed that both strains were effective to control white grubs. The mortality rates increased significantly with the increasing concentrations of the conidial suspension. The results also showed that both strains of $M$. anisopliae had a pathogenic effect on the white grubs. Among different concentration of indigenous strain, the concentration of $1.04 \times 10^{8}$ and $2.08 \times 10^{7}$ spores $/ \mathrm{ml}$ caused mortality of $97.8 \%$ and $78.1 \%$, respectively. This result is somehow similar with the result of G.C. (2006), where he calculated $73 \%$ mortality with the concentration of $1 \times 10^{7}$ spores $/ \mathrm{ml}$ and a mortality of $82.5 \%$ was reported by Dhital (2008) for the same concentration. Higher mortalities (up to 100\%) of larvae, pupae and adults of Brontispa longissima (Chrysomelidae, Coleoptera) were observed by Liu et al. (1989) with local isolates of $M$. anisopliae which might be due to the sophisticated bioassay technique and the lab facility. He also reported an average mortality of $86.7 \%$ of same insect with a range of $25 \%-98 \%$. Likewise, indigenous isolates of $M$. anisopliae caused mortalities of $64.3-77.7 \%$ under laboratory conditions with forth instar larvae of silkworm (Acharya, 2005). Similarly, an M. anisopliae suspension containing $4 \times 10^{9}$ conidia/ml caused $96 \%$ mortality of Ixodes scapularis (Acari: Ixodidae) under laboratory conditions (Benjamin et al., 2002). In the same way, there was $94 \%$ adult mortality of Anopheles stephensi (Diptera: Culicidae), a vector of Malaria, at $10^{6} \mathrm{conidia} / \mathrm{ml}$ (Kannan et al., 2008). Strains of M. anisopliae showed good potential to control adult banana weevils with mortalities up to $60 \%$ (Gold et al, 2002).

The $\mathrm{LC}_{50}$ values resulting from an indigenous and a commercial strain were $5.5 \times 10^{5}$ spores $/ \mathrm{ml}$ and $1.89 \times 10^{6}$ spores $/ \mathrm{ml}$, respectively. Similar finding was observed by Rodriguez et al. (2004) with the $\mathrm{LC}_{50}$ value of $5 \times 10^{4}$ conidia/ml for the isolate Qu-M270 against the white grub Hylamorpha elegans Burm (Coleoptera: Scarabaeidae). In the same way, Caston (2008) found an LC 50 of $3.1 \times 10^{4}$ conidia/ml for M. anisopliae isolate IMI098378 when tested against adults of the black maize beetle (Heteronychus ficas Coleoptera: Scarabaeidae). When using oil suspensions, the same author obtained $\mathrm{LC}_{50}$ ranging from $1.4 \times 10^{4}$ to $1.4 \times 10^{8}$ conidia/ml under laboratory condition at $28^{\circ} \mathrm{C}$, Further, the author observed variable $\mathrm{LC}_{50}$ at different temperatures during the experiments. Vanninen et al. (1999) found M. anisopliae isolates, applied at $1 \times 10^{7}$ spores/larvae to be superior to $B$. bassiana in infecting Delia radicum Anthomyiidae, Diptera larvae.

In the laboratory, the indigenous fungus and the commercial product of M. anisopliae showed efficacy to control white grubs. Although statistically not significant, the native fungus showed a better performance and a higher virulence against white grubs in the laboratory than the commercial product based on a non-native isolate. This is probably due to the use of freshly produced material and the better adaptation of the native fungus to the local conditions like soil properties, host species and temperatures. Since both fungi were found effective under laboratory conditions, field studies are necessary to evaluate the field efficacy of the fungi against white grubs.

\section{CONCLUSION}

From these results it is concluded that the tested entomopathogenic fungi have potential as microbial control agents in managing white grubs. Research should be continued to obtain more virulent strains of the fungus. As indigenous and commercial strains of $M$. anisopliae were effective against of $C$. acuta it is imperative to test against other important insect pests of Nepal. As laboratory work was encouraging it should be tested under farmers field condition. If it proves that entomopathogenic fungi are an effective tool in controlling pest insects, they should be integrated in pest management programs and replace synthetic insecticides. 


\section{ACKNOWLEDMENT}

This study is part of a collaborative project between the Nepal Agricultural Research Council (NARC), the International Potato Center (CIP), Peru, and the Institute of Agriculture and Animal Science (IAAS) funded by the Austrian Development Agency (ADA), Austria, and the German Federal Ministry for Economic Cooperation and Development (Bundesministerium für wirtschaftliche Zusammenarbeit und Entwicklung, BMZ), Germany. The authors are thankful to all those who provided technical and financial support to conduct this research.

\section{REFERENCES}

Acharya, N. R., 2005. Laboratory evaluation of entomogenous fungus, Metarhizium anisopliae (Metsch.) Sorokin against silkworn, Bombyx mori L. and earthworm Eiseina fetida (SAV.). M. Sc. Thesis, Institute of Agriculture and Animal Science, Tribhuwan University, Nepal. 125p.

Benjamin, M. A., E. Zhioua, and R. S. Ostfeld., 2002. Laboratory and field evaluation of the Entomopathogenic fungus Metarhizium anisopliae (Deuteromycetes) for controlling questing adult Ixodes scapularis (Acari: Ixodidae). Journal of Medical Entomology 39(5):723-728.

Burges, H. D and E. M. Thomson., 1971. Standardization and assay of microbial insecticides In: H. D. Burges and N. W. Hussey (eds.) Microbial Control of Insects and Mites. Academic Press, London, UK. pp. 591 620.

Butt, T. M., C. W. Jackson and N. Magan., 2001. Introduction fungal biological control agents: Progress, problems and potential. In: T.M. Butt, C.W. Jackson and N. Magan (eds.) Fungal Biological Control Agents: Progress, Problems and Potential. CABI Publishing, Wallingford, UK. pp. 1-8.

Caston, M., 2008. The efficacy of two isolates of Metarihizium anisopliae (Metschin) Sorokin (Deuteromycotina: Hypomycetes) against the adults of the black maize beetle Heteronychus licas Klug (Coleoptera: Scarabidae) under laboratory conditions. African Journal of Agricultural Research 3(4):259-265.

Dhital, N. 2008., Efficacy of Entomopathogenic fungus (Metarhizium anisopliae) (Metsch.) Sorokin and biorational compounds against white grubs (Coleoptera: Scarabaeidae) in Chitwan, Nepal. 119p.

Ferron, P. 1985., Fungal control. In: G. A. Kerkut and L. I. Gilbert (eds.) Comprehensive Insect Physiology, Biochemistry and Pharmacology. Pergamon, Oxford. pp. 313-346.

Fuxa, J. R. 1987., Ecological considerations for the use of entomopahtogens in IPM. Annual Review of Entomology 32:225- 251.

GC. Y. D. 2006., White grubs (Coleoptera: Scarabaeidae) associated with Nepalese agriculture and their control with the indigenous entomopathogenic fungus Metarhizium anisopliae (Metsch.) Sorokin. Ph. D. Thesis, University of Basel, Switzerland. 250p.

Gold, C. S., B. Pinese and J. E. Pena., 2002. Pests of banana In: J. E. Pena, J. L. Sharp and M. Wysoki (eds.) Tropical Fruit Pests and Pollinators: Biology, Economic Importance, Natural Enemies, and Control. CABI Publishing, Wallingford, UK. pp.342-350.

Guppy, J. C. and G. D. Harcourt., 1970. Spatial pattern of the immature stages and teneral adults of Phyllophaga spp. (Coleoptera: Scarabaeidae) in permanenet meadow. Canadian Entomologist 102:1345-1359.

Gurung, J. D., 1985. Participatory approaches to agricultural technology promotion with women in the hills of Nepal. Mountain Farming System Discussion Paper, ICIMOD, Kathmandu, Nepal. 9p.

Joshi, S. L., B. B. Karmacharya and B. R. Khadge. 1991. Plant protection trainer's manual No. 14. Manpower Development Agriculture Project. Kathmandu, Nepal. 396p.

Katuwal, S. P., 1998. Farmers are the key source of research feedback: A case study of year round maize production at Badhe lower belt, Dhankuta. Working Paper PAC, Dhankuta, Nepal. 229p.

Kannan, S. K, K. Murugan, A. N. Kumar, N. Ramasubramanian and P. Mathiyazhagan.,2008. Adulticidal effect of fungal pathogen, Metarhizium anisopliae on malarial vector Anopheles stephensi Diptera: Culicidae). Africal Journal of Biotechnology 7(6):838-841.

Khanal, D., Y. D. GC., Y. P. Giri., M. Sporleder. and R. B. Thapa., 2014. Efficacy of strains of Metarhizium anisopliae(Metsch) Sorokin with their different preparations against white grub (chiloloba acuta) in vitro in Nepal. The Journal of Agriculture and Environment.14:46-57

Liu, S. D., S. C. Liu and J. F. Shiar., 1989. Microbial control of coconut leaf beetle (Brontispa longissima) with green muscardine fungus, Metarhizium anisopliae var. anisopliae Journal of Invertebrate Pathology 53:307-314.

Maharjan, R., S. Aryal, B. P. Mainali, S. Bista, D. N. Manandhar, Y. P. Giri and R. B. Paneru., 2004. Survey on magnitude of insecticides use in vegetable crops. In: B. B. Khatri. B. P. Sharma, P. P. Khatiwada, K. P. Paudyal, B. R. Khadge and H. N. Regmi (eds.) Proceeding of the $4^{\text {th }}$ national workshop on horticulture. Advances of Horticultural Research in Nepal, 2-4 March, 2004, Kathmandu. Horticulture Research Division and National Agriculture Research Institute, Nepal Agricultural Research Council, Khumaltar. Lalitpur. pp. 390-394.

Mazodze, R. P. Zvoutete., 1999. Efficacy of Metarhizium anisopliae in the control of blackmaize beetle in the Southeast lowveld of Zimbabwe. Journal of Crop Protection. 18(5):571-515.

Meynell, G. G. and E. Meynell., 1965. Theory and practice in experimental bacteriology. Cambridge University Press, Cambridge, UK. 400p. 
NMRP. 1997. Annual report. Lumle Agriculture Research Centre, Pokhara, Kaski, Nepal. 26p.

Oya, S. 1995. Control of Scarabaeid larvae in sweet potato by the entomopathogenic nematode Steinernema kushidai. In: Geraldine Grey (ed.) Biological Control in Systems of Integrated Pest Management. FFTC, Book series no. 47p.

Oya, S. 1996. Control of Scarabaeid larvae on sweet potato by Entomopathogenic nematode, Steinernema kushidai Mumiya. In; Proceeding of the International Symposium on the Use of Biological Control Agents under Integrated Pest Management, December 1996. FFTC Book Series No. 47. Food and Fertilizer Technology Center Republic of China. Taiwan.pp. 70-77.

Palikhe, B. R., P. R. Addhikari and L .P. Kharel. 2003. Present status of plant protection services in Nepal. In: Proceedings of a Nation Seminar, Kathmandu, 25-26 September, 2002.. F.P. Neupane (ed.) Integrated Pest Management in Nepal, Himalayan Resources Institute, Kathmandu, Nepal. pp.11-21.

Pokhrel, M. R. 2004. Field survey of white grubs and laboratory evaluation of Metarhizium anisopliae (Metsch.) Sorokin for its control with side effects on Bombyx mori L in. M. Sc. Ag. Thesis (Unpublished), Tribhuvan University, Institute of Agriculture and Aninal Science, Rampur, Chitwan, Nepal.134p.

Potter, D. A., C. G. Patterson and C. T. Redmond. 1992. Influence of turf grass species and tall fescue endophyte on feeding ecology of Japanese beetle and Southern masked chafer grubs. Journal of Economic Entomology 85:900-909.

Prasad, S. K. and C. Thakur. 1959. White grub Lachnosterna consanguinea Blanch: A new menace to to sugarcane. Indian journal of Entomology 21:184-189.

Raodeo, A. K. 1974. White grubs menace in Maharastra State. White Grubs Newsletter 1: 11-13.

Rodriguez, R., A. France and M. Gerding. 2004. Evaluation of two strains of Metarhizium anisopliae var. anisopliae Burm. (Coleoptera: Scarabaeidae) larvae. Agricultura Tecchnica 64(1):17-24.

Schweigkofler, W. and R. Zelger. 2002. Were control measures responsible for the decline of Melolontha populations in South Tyrol. In: S. Keller (ed.) Integrated Control of Soil Pest "Melolontha" Proceedings of the Meeting, 24-26 September 2001.IOBL, Switzerland,. IOBC/WPRS Bulletin 25:65-72.

Strasser, H., A. Forer, and F. Schinner. 1997. Development of media for the selective isolation and maintenance of virulence of Beauveria brongniartii. In: T.A. Jacksonand T.R. Glare, (eds) Proceeding of $3^{\text {rd }}$ International Workshop onMicrobial Control of Soil Dwelling Pests. Agresearch Lincoln, New Zealand. pp. 125-130.

Upadhyaya, N. S. 2003. Status of community integrated pest management in Nepal. In: F. P. Neupane (ed.) Proceeding of a national seminar on integrated pest management in Nepal. 25-26 September, 2002, Kathmandu. Himalayan Resource Institute, Kathmandu, Nepal. pp.209- 216.

Vanninen, I., H. Hokkanen and J. Tyni-Juslin. 1999. Attempts to control cabbage root flies. Delia radicum (L) and Delia floralis (Fall) (Diptera: Anthomyiidae), with entomopathogenic fungi: Laboratory and greenhouse tests. Journal of Applied Entomology 123:107-113. 